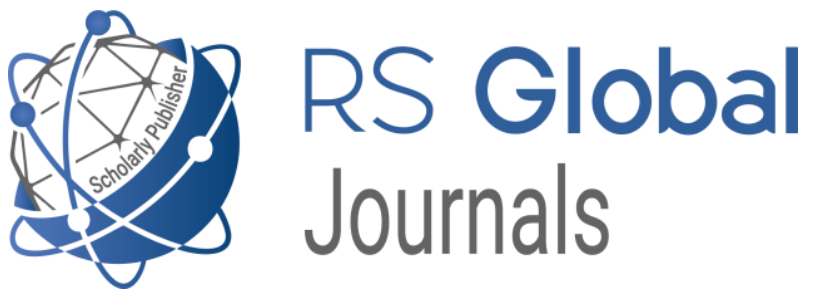

Scholarly Publisher

RS Global Sp. z O.O.

ISNI: 0000000484952390

Dolna 17, Warsaw, Poland 00-773

Tel: +48226022703

Email: editorial_office@rsglobal.pl

JOURNAL International Journal of Innovative Technologies in Social Science

p-ISSN

$2544-9338$

e-ISSN

2544-9435

PUBLISHER

RS Global Sp. z O.O., Poland

ARTICLE TITLE

Features of anxiety disorder in women of different ages during pregnancy according to the Taylor anxiety scale

AUTHOR(S)

Molotokas Antonina

Molotokas Antonina. (2020) Features of anxiety disorder in women of different ages during pregnancy according to the Taylor

ARTICLE INFO anxiety scale. International Journal of Innovative Technologies in Social Science. 6(27).

doi: 10.31435/rsglobal_ijitss/30092020/7150

DOI

https://doi.org/10.31435/rsglobal_ijitss/30092020/7150

RECEIVED

11 August 2020

ACCEPTED

10 September 2020

PUBLISHED

16 September 2020

LICENSE

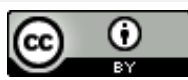

This work is licensed under a Creative Commons Attribution

4.0 International License.

(C) The author(s) 2020. This publication is an open access article. 


\title{
FEATURES OF ANXIETY DISORDER IN WOMEN OF DIFFERENT AGES DURING PREGNANCY ACCORDING TO THE TAYLOR ANXIETY SCALE
}

\author{
Molotokas Antonina \\ PhD student, Faculty of Psychology, Psychodiagnostics and Clinical Psychology Department, \\ Taras Shevchenko National university of Kyiv, Ukraine \\ ORCID ID: https://orcid.org/0000-0002-0061-1528
}

DOI: https://doi.org/10.31435/rsglobal_ijitss/30092020/7150

\section{ARTICLE INFO}

Received 11 August 2020

Accepted 10 September 2020

Published 16 September 2020

\section{KEYWORDS}

anxiety, depression, pregnancy, trimesters of pregnancy, preeclampsia, childbirth, gestational period, emotional sphere, diagnostic.

\begin{abstract}
The article deals with the problem of anxiety disorders in pregnant women, the mechanisms of development of increased anxiety in pregnant women and the psychological and physiological causes that make them. A theoretical analysis of the problem of increased anxiety in pregnant women and the reasons that cause it are presented. Anxiety noted by the most pregnant women is believed to be a major factor in allowing the line between women with normal physiological pregnancy and complicated pregnancy. The results of an empirical study showing differences in the manifestation of anxiety states in pregnant women in different trimesters of pregnancy and depending on the age of the pregnant woman are highlighted. Based on J. Taylor's method of determining anxiety in the survey of pregnant women, we found high and extremely high anxiety in almost half of them. Analyzing the manifestations of anxiety levels in pregnant women of all ages, we found a low preference for the youngest pregnant women in the sample - in $40 \%$ of young women under 20 years age. In different trimesters of pregnancy, anxiety manifests itself differently, namely, in the second trimester, most women experience the lowest levels of anxiety, while in the first and third trimesters, women experience the highest levels of anxiety, which may be due to many factors, including early pregnancy and fear of childbirth at the end.
\end{abstract}

Citation: Molotokas Antonina. (2020) Features of anxiety disorder in women of different ages during pregnancy according to the Taylor anxiety scale. International Journal of Innovative Technologies in Social Science. 6(27). doi: 10.31435/rsglobal_ijitss/30092020/7150

Copyright: (C) 2020 Molotokas Antonina. This is an open-access article distributed under the terms of the Creative Commons Attribution License (CC BY). The use, distribution or reproduction in other forums is permitted, provided the original author(s) or licensor are credited and that the original publication in this journal is cited, in accordance with accepted academic practice. No use, distribution or reproduction is permitted which does not comply with these terms.

Introduction. Numerous and complicated changes occur in a woman's body during pregnancy. These physiological and psychological changes create conditions for fetal development, prepare a woman's body for childbirth and breastfeeding a newborn (Filippova, 1996).

The development of depressive and anxiety disorders of the non-psychotic register may be due to the specific personal characteristics of women in combination with a dysfunction of the system of interpersonal relationships, relevant and unresponsive past stressors and a set of social factors that lead to a deterioration in quality of life (McNeil, Blennow, 1988).

Considerable attention should be paid by experts to the occurrence and exacerbation of anxiety, depressive disorders and neurotic reactions to stress at different stages of pregnancy.

Thus, it is proved that the most dangerous for fetal development are pathological reactions to stress and the appearance of affective pathology in the second and third trimesters of pregnancy. The effects of stress in pregnant women negatively affect the psychophysiological characteristics of infants at birth and are considered similar to those in mothers addicted to smoking. The mechanisms of development of psychopathological symptoms of non-psychotic level are determined by the ratio of 
personality typology, degree of personal maturity, socio-psychological factors, the nature of social functioning (Pushkareva, 2017).

Purpose of the article is to show features of anxiety disorder during pregnancy and how its severity can be different according to various age categories.

\section{Theoretical background.}

The most common emotional disorders encountered during gestation are anxiety and anxietydepressive disorders. Anxiety noted by the most pregnant women is believed to be a major factor in allowing the line between women with normal physiological pregnancy and complicated pregnancy (Kolesnikov, 2012).

In this regard, obstetricians and gynecologists to provide effective care to pregnant women need data on their current psychological status, which is largely determined by the state of the emotional sphere. Such information can be obtained using the method of determining the type of psychological component of gestational dominance, which reflects not only the nature of the main significant relationships of a pregnant woman, but also the features of her emotionality (Nechaeva, 2005).

An important role in the pathogenesis of psycho-emotional disorders in women during pregnancy is played by the premorbid level of personality functioning, which prevails in early pregnancy - the level of maturity of gender identity, which the woman has acquired so far. It has been proven that during pregnancy there are changes in a woman's emotional sphere in the direction of increasing lability. A woman becomes more sensitive and more susceptible to mood swings (Targum, 1979).

During pregnancy, the phenomenon of excitation increase in the subcortical structures of the brain, and in its cortex - signs of induced inhibition. A mature level of personality functioning correlates with better adaptation to the state pregnancy, more flexible adaptation to hormonal (internal) and social (external) changes during pregnancy (Evans, Heron, 2001).

A number of foreign studies have shown that anxiety and depressive disorders in women during pregnancy need to be detected and corrected early due to their significant negative impact on pregnancy, childbirth, the postpartum period and further psychophysical development and social adaptation of the child (Beck, 1996).

Anxiety and depressive disorders in women during pregnancy can be predictors of anxiety and depressive disorders in mother during the first year of child`s life, which adversely affects a woman's adaptation to motherhood and causes abnormalities in early child development (Figueiredo, Conde, 2011).

The risk of developing psychosis of the gestational period in the general population is 0.1 $0.25 \%$. At the same time, postpartum psychoses account for $45 \%-86 \%$ of all psychoses, for lactation (during the feeding period) - $10 \%-42 \%$ and psychoses of the pregnancy period - $3 \%-15 \%$. It is considered that the level of severe mental disorders during pregnancy is the same or even lower compared to the level of soreness outside of childbirth. Postpartum psychoses occur at a frequency of 1-2 per 1000 births (Targum, 1979)

Normal is a slight increase in the level of anxiety and the occurrence of fears in pregnant women who do not have sufficient information about how the pregnancy will be proceed, how will be going the development of the prenate, with what result will the delivery occur. Thus, anxiety becomes a mechanism for the adaptation of women to her new state. In some women, anxiety becomes pathological and leads to the formation of an anxious variant of gestational dominance (Eydemiller, Dobryakov, Nikolskaya, 2003).

The formation of the anxious component of gestational dominance is facilitated by the following factors:

- accidental pregnancy

- manipulative nature of pregnancy motives

- extramarital pregnancy

- marital disharmony

- unfavorable material and living conditions

- personal characteristics (anxiety, low self-esteem, etc.)

- somatic or mental illness

In such women, an anxious style of experiencing pregnancy is an important component (Filippova G.G., 1999). At the same time, against the background of anxious experiences, pregnancy is perceived by the woman herself as a state of somatic illness. 
The age of a woman under the age of 18 is rightly considered by many researchers to be an increased risk factor for the development of neuropsychiatric disorders during pregnancy period. The age of a pregnant woman over 35 years, in terms of B. L. Welles-Nystrom and P. de Chateau, correlates with greater anxiety. They found that pregnant women in this age group were more concerned about their health and the health of the baby, about childbirth, motherhood, breastfeeding. (Welles-Nystrom B. L., Chatau de P., 1987)

Methodology. The study of the features of anxiety in pregnant women was conducted on the basis of the Department of Pathology and Women's Consultation of the Maternity Hospital No. 3 (Kyiv). The procedure of research registered at the women's consultation and obstetric ward and pathology department of pregnancy in Maternity hospital No. 3 (Kyiv). For the most accurate diagnosis of the level of anxiety in pregnant women, we used Taylor Manifest Anxiety Scale.

The Manifest Anxiety Scale (MAS) is a personality questionnaire. Designed to measure manifestations of anxiety. Published by J. Taylor in 1953. The scale statements were selected from a set of statements from the Minnesota Multidimensional Personality Inventory (MMPI). The choice of items for the scale of "manifestations of anxiety" was carried out on the basis of an analysis of their ability to distinguish between persons with "chronic anxiety reactions".

Results. On the basis of the methodology of determining the level of anxiety by J. Taylor in pregnant women, they have shown result with high and increased anxiety. (Fig.1):

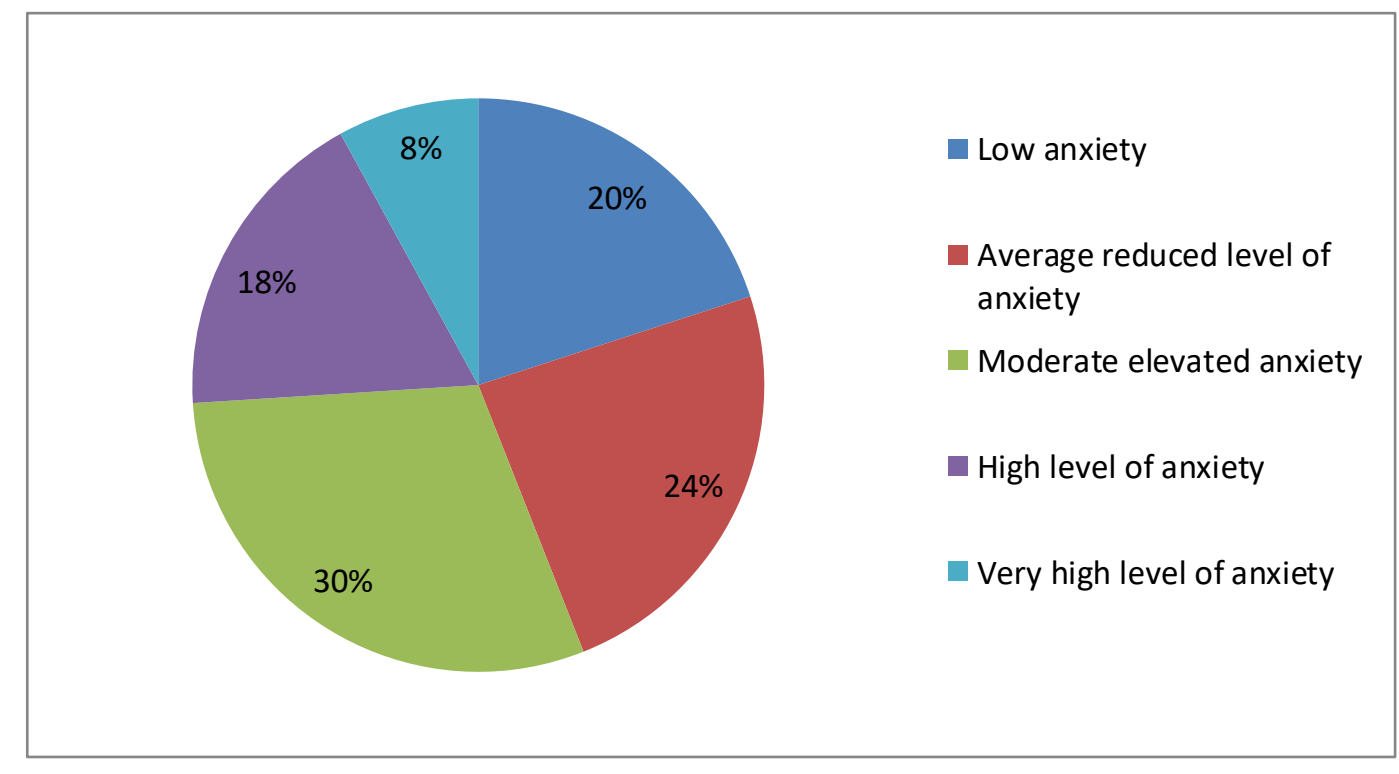

Fig.1. Anxiety in pregnant woman (according to Taylor Manifest Anxiety Scale (MAS))

$30 \%$ of pregnant women have a moderate level of anxiety, which is associated with health and other problems. $24 \%$ of respondents have an average low level of anxiety, another $20 \%$ have a low level. However, $18 \%$ have a high level of anxiety, and $8 \%$ have a very high level of anxiety, they have not only psychological signs, but also somatic symptoms of anxiety, frequent mood swings, sweating, tremors and more.

Analyzing the manifestations of anxiety levels in pregnant women of different ages, we found a predominance of low levels in the youngest pregnant women in the sample - in $40 \%$ of young women under 20 years. We assume that these young women do not yet know what to be afraid of, have an easy attitude to life, prefer a careless attitude to their health, to the state of pregnancy, the future child, and therefore are less likely to worry about these reasons.

Another $28 \%$ of young women under the age of 20 have an average level of anxiety. Among older women aged 20-29 years, the average increased level of anxiety prevails (40\%), about a third have an average reduced level (28.6\%), but these pregnant women also have high and very high levels (17.1\% and $2,9 \%$, respectively). 
Table 1. Anxiety levels of the studied pregnant women of different ages

\begin{tabular}{|c|c|c|c|c|c|c|c|c|c|c|}
\hline \multirow[t]{2}{*}{ Age } & \multicolumn{2}{|c|}{$\begin{array}{c}\text { Total } \\
(\mathrm{n}=100)\end{array}$} & \multicolumn{2}{|c|}{$\begin{array}{l}\text { Age under } \\
20 \text { years } \\
(\mathrm{n}=25)\end{array}$} & \multicolumn{2}{|c|}{$\begin{array}{c}\text { Age } 20-29 \\
\text { years } \\
(\mathrm{n}=35)\end{array}$} & \multicolumn{2}{|c|}{$\begin{array}{c}\text { Age } 30-39 \\
\text { years } \\
(\mathrm{n}=35)\end{array}$} & \multicolumn{2}{|c|}{$\begin{array}{c}\text { Over } 40 \\
\text { years } \\
(n=5)\end{array}$} \\
\hline & $\mathrm{n}$ & $\%$ & $\mathrm{n}$ & $\%$ & $\mathrm{n}$ & $\%$ & $\mathrm{n}$ & $\%$ & $\mathrm{n}$ & $\%$ \\
\hline Low & 20 & $20 \%$ & 10 & $40 \%$ & 4 & $11,4 \%$ & 6 & $17,1 \%$ & & \\
\hline Average reduced & 24 & $24 \%$ & 4 & $16 \%$ & 10 & $28,6 \%$ & 10 & $28,6 \%$ & & \\
\hline Moderate elevated & 30 & $30 \%$ & 7 & $28 \%$ & 14 & $40 \%$ & 9 & $25,7 \%$ & & \\
\hline High & 18 & $18 \%$ & 4 & $16 \%$ & 6 & $17,1 \%$ & 5 & $14,3 \%$ & 3 & $60 \%$ \\
\hline Very high & 8 & $8 \%$ & & & 1 & $2,9 \%$ & 5 & $14,3 \%$ & 2 & $40 \%$ \\
\hline
\end{tabular}

For even older pregnant women aged 30-39 years, the average reduced and inflated levels of anxiety are equally preferable (in $28.6 \%$ and $25.7 \%$ ), but $14.3 \%$ of respondents have high and very high levels of anxiety, which are manifested not sporadically under heavy loads and stressful situations, but constantly, these respondents are constantly worried, waiting for bad news, worrying about "everything in the world", sometimes they even think that this does not happen when you can relax and not worry about anything. The last subgroup of surveyed pregnant women over the age of 40 found a predominance of high (60\%) and very high levels (40\%) of anxiety.

The oldest of the sample of respondents are very worried about their own health, the health of the child, the course of pregnancy, various financial problems that accompany the process of pregnancy and care for the newborn child. It is these respondents who are most concerned about how they will raise and educate a child, whether they will be able to give it a good future, whether they will have the strength and resources to raise it as best they can.

Discussions. Based on the results of our empirical research and detailed consideration of theoretical material in the field of psychology of pregnant women and anxiety disorders, which are common in women of different ages, we can highlight the importance of further study of anxiety and anxiety disorders in pregnant women, promoting the development and introduction to the general medical community of diagnostic material to work with emotional disorders in pregnant women and timely diagnosis of these disorders for further successful correction, which, in turn, minimizes the negative impact on the fetus.

The main objective of our study was to show that the problem of anxiety in pregnant women is present, even if it is silent and ignored. Our goal is to introduce a psycho-diagnostic background in maternity hospitals, to introduce the principle of emotional involvement of a doctor in obstetric practice, to develop current studying programs for this issue.

The issue of diagnosing emotional conditions in women during pregnancy is currently very acute in the field of obstetrics and psychodiagnosis. Over the last 10 years, the issues of anxiety and depressive disorders during pregnancy have been raised several times in domestic science, which means that there is no proper level of development of this important medical and psychological issue.

Conclusions. Analyzing the manifestations of anxiety levels in pregnant women of different ages, we found that low-level anxiety predominates in the youngest pregnant women in the sample $-40 \%$ of young women under 20 years of age. We assume that these young women do not yet know what to be afraid of, have an easy attitude to life, prefer a careless attitude to their health, to the state of pregnancy, the future child, and therefore are less likely to worry about these reasons. While we found the highest levels of anxiety in older women, who are more concerned about their health and the possible scenario of childbirth at an older age, and what consequences this may have for the health of the unborn child.

In psychological terms, pregnancy often acts as a period of crisis. During pregnancy, a woman's self-consciousness, her relationship with the outside world changes significantly, there is a need for a total change in the usual way of life, use in the role of the future mother. This allows us to consider pregnancy as a special condition, different from the state of norm or pathology, health or disease.

The lack of a system of qualified, specialized psychological, psychiatric and psychotherapeutic care for pregnant women greatly complicates the normal development of pregnancy and fetal development in women with anxiety and depressive disorders. Currently, there is a significant increase in risk groups for obstetric and perinatal pathology and undoubtedly influenced by psychological factors. 


\section{REFERENCES}

1. Bárbara Figueiredo, Ana Conde (2011). Anxiety and depression symptoms in women and men from early pregnancy to 3-months postpartum. Journal of affective disorders, No. 132, 146-157.

2. Beck C.T. (1996). A meta-analysis of predictors of postpartum depression. PubMed, No. 45, 297-303.

3. Eydemiller E.G., Dobryakov I.V., Nikolskaya I.M. (2003). Semeynyiy diagnoz i semeynaya psihoterapiya: ucheb. posobie. SPb: Rech.

4. Evans J. (Ed.). (2001). Cohort study of depressed mood during pregnancy and after childbirth. BMJ, 323, 257. DOI: https://doi.org/10.1136/bmj.323.7307.257

5. Filippova, G.G. (Ed.). (1996). Razvitie materinskogo povedeniya v ontogeneze. Psihologiya segodnya. Ezhegodnik Rossiyskogo psihologicheskogo obschestva, 3, 133.

6. Kolesnikov I. (2012). Nevroticheskie depressivnyie rasstroystva $i$ semeynoe funktsionirovanie $u$ beremennyih zhenschin. Retrieved from http://mprj.ru/archiv_global/2012_5_16/nomer/nomer05.php

7. McNeil T.F., Blennow G. A. (1988). Prospective study of postpartum psychoses in a highrisk group. Relationship of birth complication and neonatal abnormality. Acta Psychiatrica Scandinavica, 78, 613-617.

8. Nechaeva, M.A. (2005). Psihologicheskie faktoryi ontogeneza materinskoy sferyi, vnutrenney kartinyi beremennosti i perinatalnogo razvitii. Chelyabinsk:YUrGU.

9. Pushkareva T.M. (2017). Algorytm skryningovoyi diagnostyky depresyvnyx ta tryvozhno-depresyvnyx rozladiv u zhinok pid chas vagitnosti ta pislya pologiv. Kyiv: Zdorov`e zhenschynu, 1, 62-66.

10. Targum S.D. (1979). Dealing with psychosis during pregnancy. JAPhA, Vol. 9, 18-21. DOI: https://doi.org/10.1016/S0160-3450(15)32299-6

11. Zabolzaeva I.V., Kozlova M.A., Cherny`sheva L.V. (1998). Vliyanie psikhotravmiruyushhikh situaczij vo vremya beremennosti na dal'nejshee razvitie rebenka. SPb: Akademiya mediko-soczial nogo upravleniya.

12. Welles-Nystrom B. L., de Chatau P. (1987). Maternal age and transition to motherhood: prenatal and perinatal assessments. Acta Psychiatr Scand, Vol.76, №6. 